\title{
The Effective Application of Task-based Television Pedagogy in Minority Preparatory of Chinese Listening and Speaking Teaching
}

\author{
Yanyan $\mathrm{Pi}^{1, \text { a }}$ \\ ${ }^{1}$ Nanchang Institute of Science \& Technology, Nanchang, Jiangxi, 330098 \\ a email
}

Keywords: Minorities, Chinese Preparatory Course, Task-based Film and Television Approach

\begin{abstract}
With the deepening of the new curriculum reform and innovation to promote the moment of course patterns gradually began to be innovative. Especially for language, mathematics and English and other main courses, various derivatives of the new teaching model not only for our current teaching efficiency level has been greatly improved, while improving the quality of teaching to a certain extent. In this paper, we heard Chinese Minority Preparatory Course of task-based teaching method brief analysis of television, from its point of view on the application of the principles of this paper discusses the practical application of the National Minority Preparatory Chinese Listening and Speaking Teaching methods Task-based film pedagogy, We hope to hear of Chinese Minority Preparatory Course teaching quality and enhance the efficiency of some help and facilitating role.
\end{abstract}

\section{Introduction}

For our Minority Preparatory Chinese teaching now, especially listening and speaking course, its main purpose is to hear the students' ability in Chinese culture. The arrangements on the basis of classroom learning and encourage students to practice the enthusiasm and initiative effectively excited during practice for students of Chinese language listening and speaking ability to get exercise, in the course of classroom teaching by the instructor and the corresponding teaching activities so that students listening and speaking ability has been improved. However, due to the special nature of minority students, want to let the enthusiasm of students and stimulate further positive initiative, it must be heard in the traditional Chinese teaching process, scientific use allow students interested in teaching resources ie teaching methods, so in order to improve their Chinese teaching efficiency.

\section{Overview of Task-Based Teaching Theory}

TBLT is made from a student-centered teaching model, which comes from the teaching philosophy of pragmatism, in the 1980's widely used in Western countries. In recent years, as China's emphasis on foreign language teaching, task-based approach gradually began to gain popularity in the teaching process in our country. Second Language Acquisition Theory and Society theory is the main theoretical basis of task-based approach, which is to develop a new form of a communicative teaching methods, the beginning is the author advocates a communicative teaching only authentic language as it thinks the most effective way to be expressed in the meaning of the environment, is a language learning [1]. From a practical teaching methods, it means teachers in the classroom teaching process, task-based, combined with teaching content and objectives set by the carefully prepared activities and develop a teaching course content with apt; students the teacher in the classroom according to the set tasks, completing tasks at the same time to carry out what they have learned to use, prompting students to learn to do more in-depth understanding and knowledge. Task-based approach is to enable students in the classroom full of learned language practice and communication, and the traditional teaching model compared to the dominant position that allows students in the teaching process has been effectively demonstrated, to further enhance the effectiveness of teaching and Teaching Quality. 


\section{Application the Principles of Task-based Teaching Pedagogy in Television Minority Preparatory of Chinese Listening and Speaking}

In the process of teaching task-based film, the degree of difficulty of the role of film and television students will accept the audio-visual effects and direct impact on classroom teaching. Most minority students learning Chinese is not a long time, relatively poor foundation. Therefore, when teaching courses, combined with the students to select the appropriate level of Chinese film and television work, I heard the Chinese teaching efficiency has a very important role [2]. Under normal circumstances, the task-based teaching methods in selected film and television works in the difficult language should not exist, nor can involve more technical terms. Select Filmography should as far as possible in the selection of historical costume drama, in which more everyday language and living conditions more suitable for teaching. The other film role, although the medical drama will appear more everyday language and life situations, but also contains a lot of medical jargon that there is a certain degree of difficulty for students to understand it. But if at the time of the relevant course content learning, it may be appropriate to excerpts intercepted. In addition, the language came out, the stock market can not be too complicated plot, otherwise difficult for students to grasp the relationship between one of the characters, this will cause the output of situational understanding and to some extent affected.

Student interest is the best teacher, having more interesting film and television works and life of many students can bring more intense appeal. In addition, the choice of film and television work, all aspects should also be taken after the student's age, interests and level of learning. Filmography as a teaching process of teaching resources will be used in teaching the Chinese language I heard the main purpose is to let the students' interest and enthusiasm fully stimulate [3]. Therefore, the choice of film and television work, should be possible to achieve effective integration of language knowledge and work interesting, the only way to encourage students in the knowledge of the language learning process, it is possible with a more positive attitude, into situation and to show understanding to acquire knowledge to go.

\section{Minority Preparatory Chinese Teaching}

I heard that most of the Chinese Department of Teaching involves a series of daily life language, so during the teaching process, it should be possible to select the relevant city life film and television works, film and television works if time is too long, the teacher may be appropriate to capture, to which the best part of teaching. On TV you can choose some aspects of urban melodrama, such as "dwelling", "struggle", "Beijing love story" and so, in these love stories will involve a lot of scenes of life and trivia, for the purposes of minority students learning Chinese You can play a great help. Teachers can also situational practice, which allows the students to reference film and television work life situations language dialogue to further practice the learned content, encourage students to Chinese speaking ability has been effectively improved. Secondly, in the movie, you can also from the point of view, such as "You Are the One", "To the youth", etc., can be applied to the relevant teaching content [4]. In addition, teachers in the choice of film and television work, but also to select some conscious and ethnic-related work, which allows students to further stimulate interest in learning. However, when you need to pay attention, the different, the required teaching resources teaching content will vary widely, so teachers in the process of teaching Chinese language heard, should strictly follow the actual teaching arrangements to rational to choose and use the only way to make the role of film and television work into full play, so that expectations of task-based pedagogy film can be achieved, so that I heard of Minority Preparatory Chinese teaching efficiency and teaching quality can be effectively improved.

In the design task of teaching, the teacher not only include teaching tasks before Film-graphy player teachers need to design, teaching task after Film-graphy finished playing students should be equally included, in addition even after a reasonable design students to complete the task of 
teaching self-evaluation, teacher evaluation and summarizing overall. First, instructional design film and television work before play, teachers should filter out suitable film and television work in advance, and this lesson students need to master the knowledge of the language determined, introduction and explain the methods specifically related to language knowledge, and to brief students the introduction of the selected video works or video clips, so that students are ready to advance in this process of teaching tools in need, and made student watch videos highlights and requirements need to master the like. Secondly, the film and television work after playing teaching design [5]. Teachers supervise students should complete the relevant task of teaching students to observe than recorded in the learning process of the key, difficult and error-prone points and 11 explain in detail, to encourage students to be more comprehensive grasp of this teaching mission of teaching content . But also to urge the students to self-evaluate and report on their own learning, the last task is completed by the teachers summarize and assess the situation.

\section{Conclusion}

All in all, with the deepening of education reform, the minority Chinese Preparatory heard teaching process, teachers only on the application of the principles of task-based teaching method to conduct a comprehensive analysis of film and television, exploring how to let the role into full play and thus ,, basis, and choose from the film and television works on two aspects of teaching task design, reasonable use of task-based teaching method for teaching film and television, so let it be able to role into full play, and thus further enhance our quality of listening and speaking teaching Chinese Minority Preparatory Course and teaching effectiveness

\section{References}

[1] Wu Jinfeng. Comparative Study of Xinjiang Ethnic Education for Ethnic Minorities mode with the National Institute of Ethnic Preparatory Training Mode [J]. Xinjiang Normal University (Philosophy and Social Sciences), 2004, 02: 146-151.

[2] Zhou Qiaoyun. The presence of Chinese Teaching Minority Students in southern Liuxiu Ming problems and countermeasures [J]. Kashgar Teachers College, 2014,02: 93-96.

[3] Yang Mei. Arbutus Situational Approach in Teaching Spoken Chinese Preparatory Exploration-Taking Hotan Teachers College as an Example [J]. Hotan Teachers College, 2012, 06: 36-41.

[4] Wu Xiaolin. Flip teaching mode and its applicability and application strategy of Xinjiang Preparatory Chinese Teaching [J]. Changji University, 2016, 03: 47-52.

[5] Jiang Fuer. Improve the quality of undergraduate education of ethnic minorities, "breach" Perspective of Xinjiang Medical Teaching Chinese [J]. Chinese National Education, 2006, Z1: 38-40. 